\title{
Combination of nadroparin with radiotherapy results in powerful synergistic antitumor effects in lung adenocarcinoma A549 cells
}

\author{
XIBING ZHUANG $^{1}$, TIANKUI QIAO ${ }^{1}$, GUOXIONG XU ${ }^{2}$, SUJUAN YUAN ${ }^{1}$, QI ZHANG ${ }^{1}$ and XUE CHEN ${ }^{1}$ \\ ${ }^{1}$ Department of Oncology and ${ }^{2}$ Center Laboratory, Jinshan Hospital, Fudan University, Shanghai 201508, P.R. China
}

Received March 14, 2016; Accepted July 19, 2016

DOI: $10.3892 /$ or.2016.4990

\begin{abstract}
Low-molecular-weight heparins (LMWHs), which are commonly used in venous thromboprophylaxis and treatment, have recently been reported to have effects on cancer metastasis in pre-clinical research studies. This study was planned to define the synergistic antitumor effects of nadroparin (a kind of LMWH) combined with radiotherapy in A549 cells. Six experimental groups were set up in our study according to the different treatment: control group; irradiation (IR) group; low dose of nadroparin group $\left(\mathrm{LMWH}_{50}, \mathrm{~L}_{50}\right)$; high dose of nadroparin group $\left(\mathrm{LMWH}_{100}, \mathrm{~L}_{100}\right) ; \mathrm{LMWH}_{50}+\mathrm{IR}$ group; $\mathrm{LMWH}_{100}+\mathrm{IR}$ group. The viability of A549 cells was assessed by Cell Counting Kit-8 (CCK-8) assay. The apoptosis of tumor cells was analyzed by flow cytometry (FCM) after treatment. The concentration of transforming growth factor- $\beta 1$ (TGF- $\beta 1$ ) in the culture supernatants was measured by enzyme-linked immunosorbent assay (ELISA). The migration and invasion of the A549 cells were tested by the Transwell chamber assay. The expression of survivin, CD147 and matrix metalloproteinase-2 (MMP-2) was analyzed by western blotting. CCK-8 assay showed that irradiation or nadroparin alone slightly inhibited the cell viability while the combined treatments significantly inhibited the cell viability in a dose- and time-dependent manner. The apoptosis rate showed greater improvement dose- and time-dependently in the groups receiving combination therapy of nadroparin and irradiation than the control group or the group receiving nadroparin or irradiation alone by FCM. ELISA assay showed that the decreased TGF- $\beta 1$ secretion was found after combined treatments with nadroparin and irradiation compared to either treatment alone. The Transwell chamber assay showed that nadroparin not only significantly suppressed the migration and invasion of A549 cells but also inhibited the enhanced ability of migration and invasion induced by X-ray irradiation. Western
\end{abstract}

Correspondence to: Dr Tiankui Qiao, Department of Oncology, Jinshan Hospital, Fudan University, 1508 Longhang Road, Shanghai 201508, P.R. China

E-mail: qiaotk@163.com

Key words: low-molecular-weight heparins, lung cancer, X-ray irradiation, matrix metalloproteinase-2, survivin blotting showed that nadroparin inhibited the upregulated effects of survivin and MMP-2 expression induced by radiation in the combined treatment groups in a dose- and timedependent manner. Moreover, the expression level of CD147 was the lowest in the combined treatment groups. This study identified that combination of nadroparin and irradiation had a strong synergistic antitumor effect in a dose- and time-related manner in vitro, which was reflected in the inhibition of cell viability, invasion and metastasis, promotion of apoptosis, inhibited secretion level of TGF- $\beta 1$ and downregulation of CD147, MMP-2 and survivin expression.

\section{Introduction}

Lung cancer has one of the highest morbidity and mortality rates worldwide. The majority of lung cancers are diagnosed at late stages, with locally advanced disease and distant metastases, and its long-term survival remains desperately poor. Radiotherapy is one of the most important therapies in these patients while recurrence and metastasis, signs of malignancy and the main cause of death in cancer patients (1), and the risk of tumor radio-resistance limit the effect of radiotherapy. Many studies have also found that radiotherapy plays a role in stimulating tumor cell growth and promoting invasiveness of tumor cells in addition to a number of common adverse reactions. Thus, looking for the effective combination therapy to enhance the antitumor effect is still urgent.

Low-molecular-weight heparins (LMWHs), obtained by the methods of enzymatic hydrolysis or chemical degradation from unfractionated heparin (UFH), relative molecular weight 3-9 kDa, was approved by the FDA in 1998 for anticoagulant therapy and has been administrated as effective anticoagulants in the prevention and treatment of thrombosis safely for many years (2), along with having potential anticancer effects and improving survival in cancer patients $(3,4)$. Furthermore, recent studies have showed that LMWHs can directly induce the inhibition of the invasion and metastasis of the cancer cells, change the cell cycle, increase the sensitivity of chemotherapy and reduce the extent of radiation-induced liver injury (5-8). Whether it has synergistic antitumor effects to radiotherapy has rarely been reported. On the basis of present studies, we used two doses of nadroparin, a kind of LMWH, combined with X-ray irradiation to treat A549 cells in order to assess the 
relevant interactions between nadroparin and radiotherapy in this study.

\section{Materials and methods}

Main instruments and reagents. A549 cell line used in this study was kindly supplied by the Shanghai Institute of Life Science, Chinese Academy of Sciences (Shanghai, China) and cultured in RPMI-1640 medium (Biowest, Nuaillé, France) supplemented with $10 \%$ fetal bovine serum (FBS). Cultures were maintained at $37^{\circ} \mathrm{C}$ in a humidified atmosphere containing $5 \% \mathrm{CO}_{2}$. Nadroparin (Fraxiparina ${ }^{\circledR}$; GlaxoSmithKline, London, UK) was obtained as standard drug formulations. The Cell Counting Kit-8 (CCK-8; Dojindo Laboratories, Kumamoto, Japan) was used to detect cell proliferation and activity. Levels of transforming growth factor- $\beta 1$ (TGF- $\beta 1$ ) in the culture supernatants was measured using a standard Quantikine enzyme-linked immunosorbent assay (ELISA) kit from R\&D Systems, Inc. (Minneapolis, MN, USA). Annexin V-fluorescein isothiocyanate (FITC) detection kit was purchased from Becton-Dickinson (San Jose, CA, USA) to detect cell apoptosis. Matrigel and Transwell chambers were purchased from Becton-Dickinson as well. Rabbit monoclonal antibodies against survivin, goat anti-rabbit horseradish peroxidase labelled secondary antibody, anti-GAPDH mouse monoclonal antibodies were purchased from Santa Cruz Biotechnology, Inc. (Santa Cruz, CA, USA). The linear accelerator was Precise 5839 (Elekta, Stockholm, Sweden).

Experimental method and grouping. This study contained six groups with different kinds of treatments: control group; irradiation group (X-ray, treated with $10 \mathrm{~Gy}$ X-ray irradiation); $\mathrm{LMWH}_{50}$ group $\left(\mathrm{L}_{50}\right.$, treated with $50 \mathrm{IU} / \mathrm{ml}$ of nadroparin); $\mathrm{LMWH}_{100}$ group ( $\mathrm{L}_{100}$, treated with $100 \mathrm{IU} / \mathrm{ml}$ of nadroparin); $\mathrm{LMWH}_{50}+\mathrm{X}$-ray irradiation group and $\mathrm{LMWH}_{100}+\mathrm{X}$-ray irradiation group $\left(\mathrm{X}+\mathrm{L}_{50}, \mathrm{X}+\mathrm{L}_{100}\right.$, treated with two doses of nadroparin and $10 \mathrm{~Gy} \mathrm{X}$-ray irradiation). Cells were seeded and incubated for $24 \mathrm{~h}$, then changed to $10 \%$ FBS-1640 with or without nadroparin overnight. Twenty-four hours later, X-ray irradiation was administered according to the experimental design. A variety of detection was performed in the next 24 and $48 \mathrm{~h}$ after radiation.

Cell viability assay. Cells ( $5 \times 10^{3}$ cells/well) were incubated in the 96-well plates and treatments were conducted as mentioned above. The CCK- 8 solution $(10 \mu \mathrm{l} /$ well $)$ was added at the indicated time, then incubated for further $1 \mathrm{~h}$ at $37^{\circ} \mathrm{C}$. The absorbance of cells in each well was measured at $450 \mathrm{~nm}$. The cell viability was expressed as percentage of the absorbance present in the treated group compared to the control group: $\left(\mathrm{OD}_{\text {treated }} / \mathrm{OD}_{\text {control }}\right) \times 100 \%$.

Assessment of cell apoptosis. In brief, $2 \times 10^{5}$ cells/well were applied to six-well plates and treated exactly as described above. The cells were harvested and centrifuged at 24 and $48 \mathrm{~h}$ after radiation and then washed twice with PBS. The cells were resuspended in $500 \mu \mathrm{l}$ of binding buffer containing $5 \mu \mathrm{l}$ FITC conjugated Annexin $\mathrm{V}$ and $5 \mu \mathrm{l}$ propidium iodide (PI), and incubated in the dark at room temperature for $15 \mathrm{~min}$. Cells were then analysed in a FACSCalibur flow cytometer (Becton-Dickinson) to differentiate apoptotic cells (Annexin V-positive and PI-negative, lower right quadrant) from necrotic cells (Annexin V/PI-positive, upper right quadrant). Fifteen thousand events were recorded for each treatment group.

Measurement of TGF- $\beta 1$ release. The cell culture supernatants were collected at 24 and $48 \mathrm{~h}$ after radiation. The culture supernatants were separated by centrifugation and stored at $-80^{\circ} \mathrm{C}$. The concentration of TGF- $\beta 1$ was measured simultaneously using an ELISA kit (R\&D Systems, Inc.).

Determination of migration and invasion. About $2 \times 10^{5}$ cells/well were seeded to six-well plates and treated exactly as described above. The cells were harvested and centrifuged at $24 \mathrm{~h}$ after radiation and maintained in serum-free RPMI-1640 for $12 \mathrm{~h}$. Cell invasion and migration were determined with or without Matrigel-coated Transwell chambers. Cells $\left(1 \times 10^{4}\right)$ were removed for migration and $2 \times 10^{4}$ cells for invasion of these treated cells were placed into the upper compartment with $100 \mu \mathrm{l}$ serum-free RPMI1640 , and the lower compartment was filled with RPMI-1640 containing $15 \%$ FBS. The chamber was then cultivated in 5\% $\mathrm{CO}_{2}$ at $37^{\circ} \mathrm{C}$ for $24 \mathrm{~h}$ to detect the cell migration and invasion. The Matrigel and cells in the upper chamber were removed, and the attached cells in the lower section were stained with $0.1 \%$ crystal violet. These cells were counted in five highpower microscope fields of vision and photographed.

Protein extraction and western blotting. Cells $\left(2 \times 10^{5}\right)$ were seeded in six-well plates and treated as described above. At the end of the treatment period ( 24 and $48 \mathrm{~h}$ after radiation), cells were washed three times in ice-cold PBS and lysed for at least $30 \mathrm{~min}$ on ice in the cold lysis buffer with $1 \mathrm{mM}$ phenylmethanesulfonyl fluoride (PMSF). Protein concentrations were measured using the Coomassie Blue Fast staining solution (Beyotime, Shanghai, China). Proteins $(50 \mu \mathrm{g})$ in each group was separated on 10-12\% SDS-PAGE and transferred to a PVDF membrane (Millipore Corp., Billerica, MA, USA) at $80 \mathrm{~V}$ for $90 \mathrm{~min}$. Membranes were blocked by TBS/T containing $5 \%$ skim milk for $3 \mathrm{~h}$, and incubated with the CD147, matrix metalloproteinase-2 (MMP-2) and survivin antibody (1:500-1:1,000 dilution) overnight at $4^{\circ} \mathrm{C}$, while the GAPDH and $\beta$-actin antibody (1:10,000 dilution) was used as an endogenous reference for quantification. Then the membranes were incubated with the secondary antibodies (1:4,000 dilution) at room temperature for $1 \mathrm{~h}$ after three washes in TBS/T. After several washes with TBS/T, the blots were detected using Immobilon ${ }^{\mathrm{TM}}$ Western Chemiluminescent HRP substrate (Millipore Corp.) and quantified using Tanon-4500 Gel Imaging System with GIS ID Analysis Software v4.1.5 (Tanon Science \& Technology Co., Ltd., Shanghai, China).

Statistical analysis. Statistical analysis was performed using the SPSS software version 20.0. Data were expressed as means \pm standard error (SE). Student's t-test was used to test the differences between groups. Differences resulting in $\mathrm{p}<0.05$ were considered to be statistically significant. All data are reported from three independent experiments. 


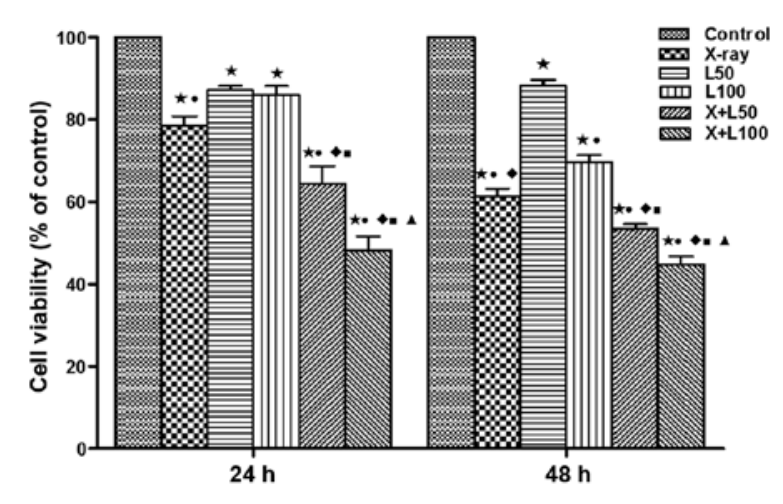

Figure 1. Effect of nadroparin and X-ray irradiation on A549 cell viability. Cell Counting Kit-8 was used to detect the cell viability of A549 cells after different treatments at different time-points, respectively. Significant differences were observed in the treated groups compared to the control group $\left({ }^{\star} \mathrm{p}<0.05, \mathrm{t}=9.492,12.889,6.753,8.153\right.$ and 14.704 at $24 \mathrm{~h}, \mathrm{t}=20.413,7.990$, $17.770,44.692$ and 29.615 at $48 \mathrm{~h}$ ). A difference from X-ray irradiation group ( $\mathrm{p}<0.05, \mathrm{t}=2.883$ and 7.256 at $24 \mathrm{~h}, \mathrm{t}=3.639$ and 6.214 at $48 \mathrm{~h}$ ); a difference from $\mathrm{L}_{50}\left({ }^{\circ} \mathrm{p}<0.05, \mathrm{t}=3.483,5.083\right.$ and 10.643 at $24 \mathrm{~h}, \mathrm{t}=11.152,19.150$ and 18.200 at $48 \mathrm{~h}, \mathrm{p}<0.05)$; a difference from $\mathrm{L}_{100}(\bullet \mathrm{p}<0.05, \mathrm{t}=4.486$ and 9.473 at $24 \mathrm{~h}, \mathrm{t}=3.264,8.095$ and 9.826 at $48 \mathrm{~h})$; a difference from $\mathrm{X}+\mathrm{L}_{50}\left({ }^{\mathrm{A}} \mathrm{p}<0.05\right.$, $\mathrm{t}=2.886$ at $24 \mathrm{~h}, \mathrm{t}=4.050$ at $48 \mathrm{~h}$ ).

\section{Results}

Effects on cell viability. This study examined the cell viability of A549 cells treated with two doses of nadroparin and X-ray radiation at different time-points (24 and $48 \mathrm{~h}$ ) using the CCK-8 assay. As shown in Fig. 1, the cell viability was inhibited to different extent compared to the control group after treatments. With the prolongation of treatment time, no significant change was observed in the inhibition of cell viability treated with low dose of nadroparin alone ( $\mathrm{L}_{50}$ group), while the cell viability was inhibited in a dose- and time-dependent manner after the other treatments (irradiation alone, high dose of nadroparin alone ( $\mathrm{L}_{100}$ group) and different dose of nadroparin combined with X-ray irradiation). Furthermore, the cell viability was significantly inhibited in the high dose of nadroparin combined with X-ray irradiation group compared to the other groups $(\mathrm{p}<0.05)$.

Cell apoptosis. LWMHs induced apoptosis of tumor cells in vitro and in vivo $(9,10)$. Our study examined whether nadroparin had synergetic contribution to tumor cell apoptosis when combined with X-ray irradiation. As shown in Figs. 2 and 3, each treatment remarkably induced A549 cell apoptosis dose- and time-dependently compared to the control group $(\mathrm{p}<0.05)$. The promotion of apoptosis induced by X-ray irradiation alone was more significant than by different dose of nadroparin alone $(\mathrm{p}<0.05)$. Furthermore, the apoptosis rate reached $17.41 \pm 0.63 \%$ in $\mathrm{X}+\mathrm{L}_{100}$ group $48 \mathrm{~h}$ after treatment, and was the highest among the experimental groups $(\mathrm{p}<0.05)$, which revealed that the higher the dose of nadroparin combined with X-ray irradiation, the more effective the result was.

Release of TGF- $\beta 1$. The concentrations of TGF- $\beta 1$ in the cell supernatants at the time-points (24 and $48 \mathrm{~h})$ after irradiation were compared among each group in Fig. 4 . We found that the TGF- $\beta 1$ levels were increased with the prolonging of time in the control group, $\mathrm{X}$-ray irradiation group and the $\mathrm{L}_{50}$ group,

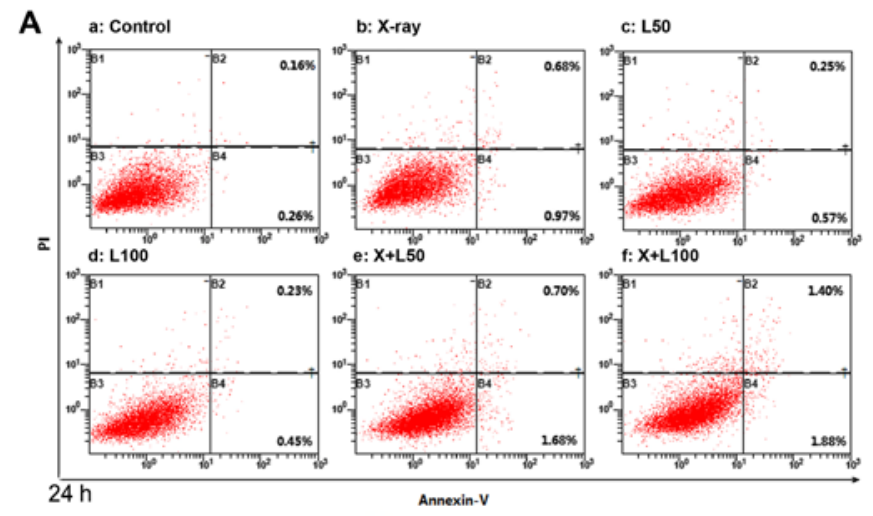

B

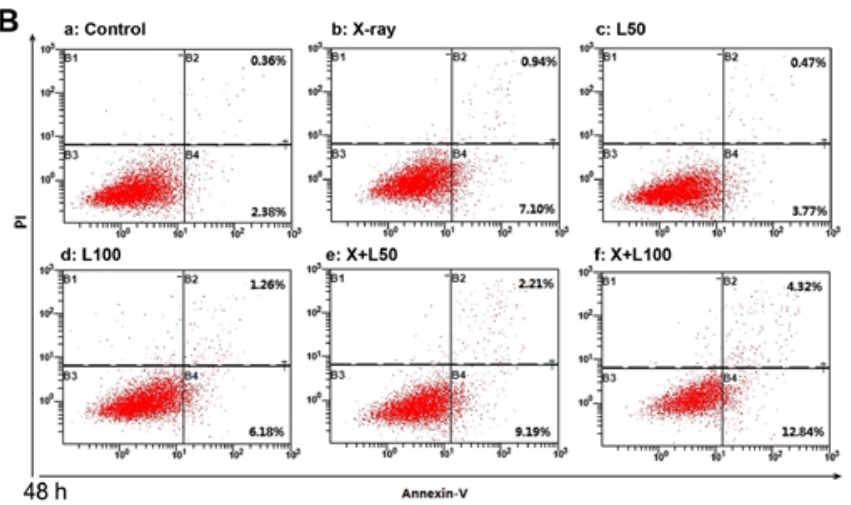

Figure 2. Apoptosis in A549 cells treated with nadroparin plus X-rays. The A549 cells were stained by Annexin V/propidium iodide (PI) and measured by flow cytometry after treatments. Bottom right quadrant, cells stained mainly by Annexin V, refers to the early apoptotic cells; top right quadrant, cells stained by both PI and Annexin V, refers to late apopototic cells; top left quadrant, cells stained mainly by PI, refers to the necrotic cells; bottom left quadrant, cells negative for both Annexin V and PI, refers to the viable cells. The high dose of nadroparin combined with X-ray irradiation induced the highest cell apoptosis (3.28\% at $24 \mathrm{~h}$ and $17.16 \%$ at $48 \mathrm{~h}$ ).

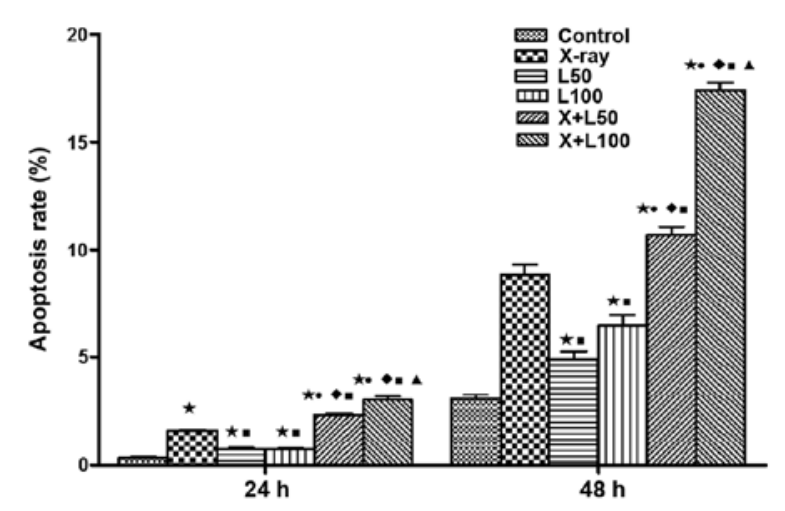

Figure 3. Apoptotic fraction of A549 cells in different experimental groups. Significant differences of A549 cell apoptosis in the treated groups were observed compared to the control group $\left({ }^{\star} \mathrm{p}<0.05, \mathrm{t}=17.307,3.635,4.964\right.$, 18.636 and 15.353 at $24 \mathrm{~h}, \mathrm{t}=11.251,4.517,6.443,18.380$ and 35.032 at $48 \mathrm{~h}$ ). The promotion of apoptosis induced by X-ray irradiation alone was more significant than by different dose of nadroparin alone but less effect was observed when combined $(-\mathrm{p}<0.05, \mathrm{t}=9.683,15.043,7.899$ and 8.523 at $24 \mathrm{~h}$, $\mathrm{t}=6.606,3.432,3.096$ and 14.371 at $48 \mathrm{~h})$. A difference from $\mathrm{L}_{50}(\bullet \mathrm{p}<0.05$, $\mathrm{t}=13.338$ and 12.525 at $24 \mathrm{~h}, \mathrm{t}=11.279$ and 24.579 at $48 \mathrm{~h}, \mathrm{p}<0.05)$; a difference from $\mathrm{L}_{100}\left({ }^{\star} \mathrm{p}<0.05, \mathrm{t}=16.415\right.$ and 13.501 at $24 \mathrm{~h}, \mathrm{t}=6.842$ and 17.866 at $48 \mathrm{~h})$; a difference from $\mathrm{X}+\mathrm{L}_{50}\left({ }^{\wedge} \mathrm{p}<0.05, \mathrm{t}=3.846\right.$ at $24 \mathrm{~h}, \mathrm{t}=13.020$ at $\left.48 \mathrm{~h}\right)$.

and the increase of the control group was the most obvious. On the contrary, with the prolonging of time, the TGF- $\beta 1$ 


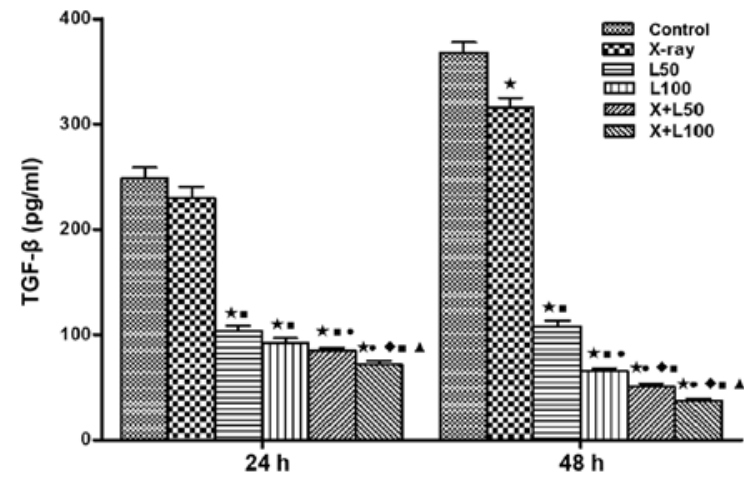

Figure 4. Concentration of transforming growth factor- $\beta 1$ (TGF- $\beta 1$ ) in cell culture supernatants. Enzyme-linked immunosorbent assay kit was used to measure TGF- $\beta 1$ levels in cell culture supernatants. The levels were of statistically significant differences among the groups. A difference from the control group $\left({ }^{\star} \mathrm{p}<0.05, \mathrm{t}=13.294,14.419,16.238\right.$ and 17.173 at $24 \mathrm{~h}, \mathrm{t}=3.817$, $22.470,28.463,29.598$ and 31.885 at $48 \mathrm{~h}$ ); a difference from X-ray irradiation group $(-\mathrm{p}<0.05, \mathrm{t}=11.173,12.253,13.802$ and 14.759 at $24 \mathrm{~h}, \mathrm{t}=20.145$ $27.037,28.312$ and 31.065 at $48 \mathrm{~h})$; a difference from $\mathrm{L}_{50}\left({ }^{\circ} \mathrm{p}<0.05, \mathrm{t}=3.384\right.$ and 5.356 at $24 \mathrm{~h}, \mathrm{t}=6.987,9.147$ and 12.513 at $48 \mathrm{~h}$ ); a difference from $\mathrm{L}_{100}$ $(* \mathrm{p}<0.05, \mathrm{t}=3.392$ at $24 \mathrm{~h}, \mathrm{t}=3.370$ and 8.318 at $48 \mathrm{~h}) ;$ a difference from $\mathrm{X}+\mathrm{L}_{50}$ $\left({ }^{\mathrm{p}}<0.05, \mathrm{t}=3.014\right.$ at $24 \mathrm{~h}, \mathrm{t}=3.703$ at $\left.48 \mathrm{~h}\right)$.

levels were significantly decreased in the $\mathrm{L}_{100}$ group and two combined treatment groups. The concentrations of TGF- $\beta 1$ in $\mathrm{X}+\mathrm{L}_{100}$ group were $71.88 \pm 5.87$ and $37.35 \pm 2.92 \mathrm{pg} / \mathrm{ml}$, respectively, at 24 and $48 \mathrm{~h}$ after treatment, which was the lowest among the experimental groups $(\mathrm{p}<0.05)$.

Cell migration and invasion. Cell migration and invasion are critical for the spreading of cancer and the formation of metastasis in vivo. As shown in Fig. 5, X-ray irradiation alone resulted in a significant increase in A549 cell migration while less migration was observed in the nadroparin alone groups in a dose-dependent manner. Furthermore, nadroparin inhibited the increase in A549 cell migration induced by X-ray irradiation in the combined treatment groups. Additionally, as shown in Fig. 6, similar results were seen in A549 cell invasion. Our result showed that X-ray irradiation promoted the ability of invasion and migration in A549 cells while nadroparin inhibited this side effect dose-dependently.

Expression levels of CD147, MMP-2 and survivin. We examined the protein expression levels of survivin, CD147 and MMP-2 using western blotting in our study to investigate the related molecular mechanism of the antitumor effect associated with nadroparin combined with X-ray radiation on A549 cells. As shown in Fig. 7, the expression levels of CD147 in A549 cells were inhibited by nadroparin in a doseand time-dependent manner while no significant change of CD147 expression was observed in the X-ray irradiation group. Furthermore, the expression levels of CD147 were the lowest in the combined treatment groups and $\mathrm{L}_{100}$ group at the time of $48 \mathrm{~h}$ after treatment $(\mathrm{p}<0.05)$. As shown in Fig. 8 , at the time of $24 \mathrm{~h}$ after treatment, the expression levels of MMP-2 were upregulated in the X-ray irradiation group while downregulated in the groups treated with nadroparin alone $(\mathrm{p}<0.05)$. Interestingly, we observed that the upregulated effects induced by radiation were inhibited by nadroparin in the combined

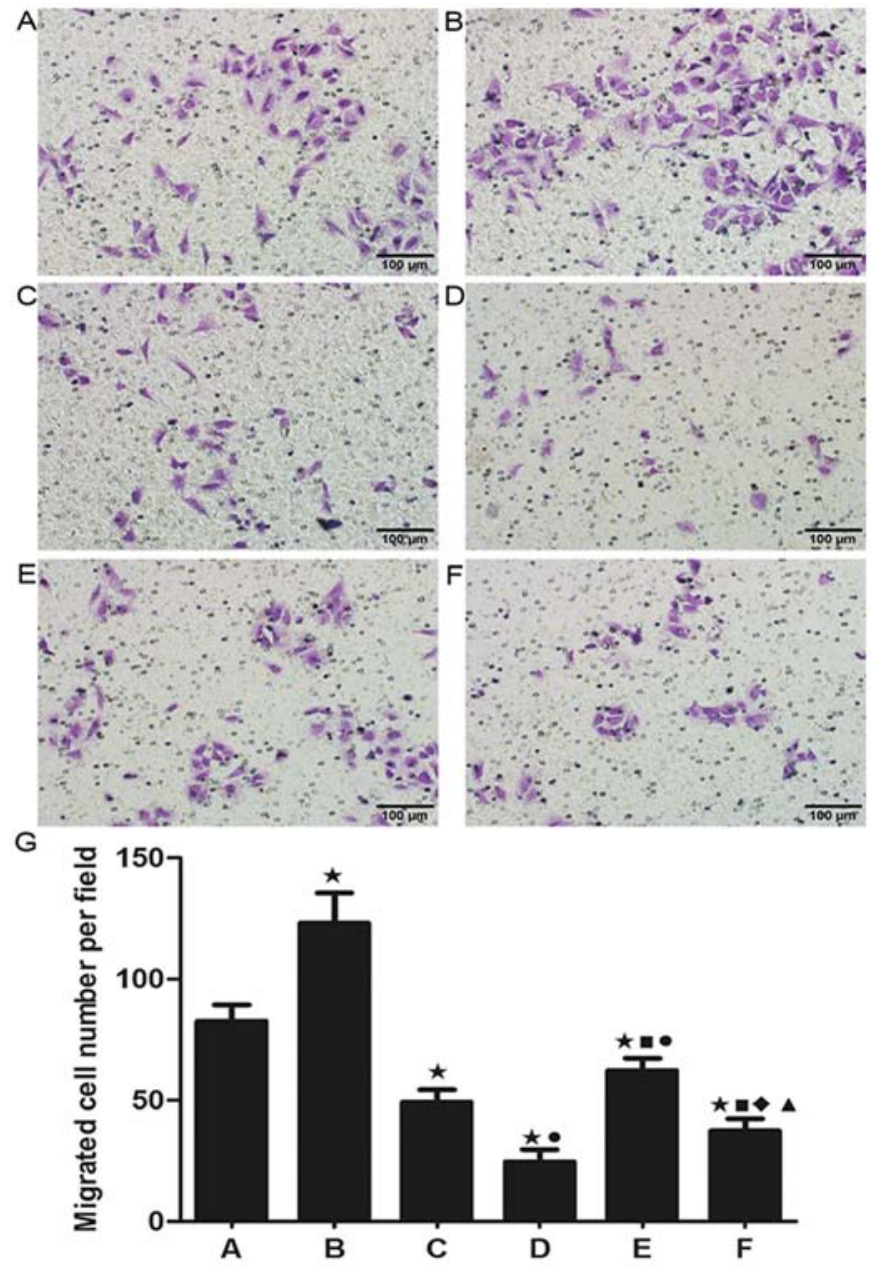

Figure 5. Detection of cell migration. (A) Control group, (B) X-ray irradiation group, (C) $\mathrm{L}_{50}$ group, (D) $\mathrm{L}_{100}$ group, (E) $\mathrm{X}+\mathrm{L}_{50}$ group, (F) $\mathrm{X}+\mathrm{L}_{100}$ group. Original amplification, x200; scale bar, $100 \mu \mathrm{m}$. (G) The migrated cell number per field in each experimental group. Twenty-four hours after treatment, the ability of cell migration was increased in the X-ray irradiation group while nadroparin alone or the combined treatments decreased the cell migration compared to the control group $\left({ }^{\star} \mathrm{p}<0.05, \mathrm{t}=4.899,6.773,11.867\right.$, 4.819 and 9.211). Nadroparin inhibited the promotion of A549 cell migration induced by X-ray irradiation in a dose-dependent manner. A difference from $\mathrm{X}$-ray irradiation group ( $\mathrm{p}<0.05, \mathrm{t}=7.803$ and 10.959$)$; a difference from $\mathrm{L}_{50}$ $\left({ }^{\bullet} \mathrm{p}<0.05, \mathrm{t}=5.944\right.$ and 3.163); a difference from $\mathrm{L}_{100}\left({ }^{\bullet} \mathrm{p}<0.05, \mathrm{t}=3.052\right)$; a difference from $\mathrm{X}+\mathrm{L}_{50}\left({ }^{\star} \mathrm{p}<0.05, \mathrm{t}=6.083\right)$.

treatment groups $(\mathrm{p}<0.05)$. Similar tendency of survivin expressions was observed at the time of $24 \mathrm{~h}$ after treatment, which is shown in Fig. 9. On the other hand, at the time of $48 \mathrm{~h}$ after treatment, the expression levels of MMP-2 were inhibited in the treated groups compared to the control group and the expression levels of survivin were downregulated in the treated groups compared to the control group while the down regulation effect induced by X-ray irradiation alone or the combined treatment was more significant than nadroparin alone $(\mathrm{p}<0.05)$.

\section{Discussion}

Radiotherapy plays an important role in the treatment of advanced lung cancer. However, the therapeutic efficacy is compromised due to the resistance to X-rays, tumor recurrence and metastasis. In addition, radiation has been shown 

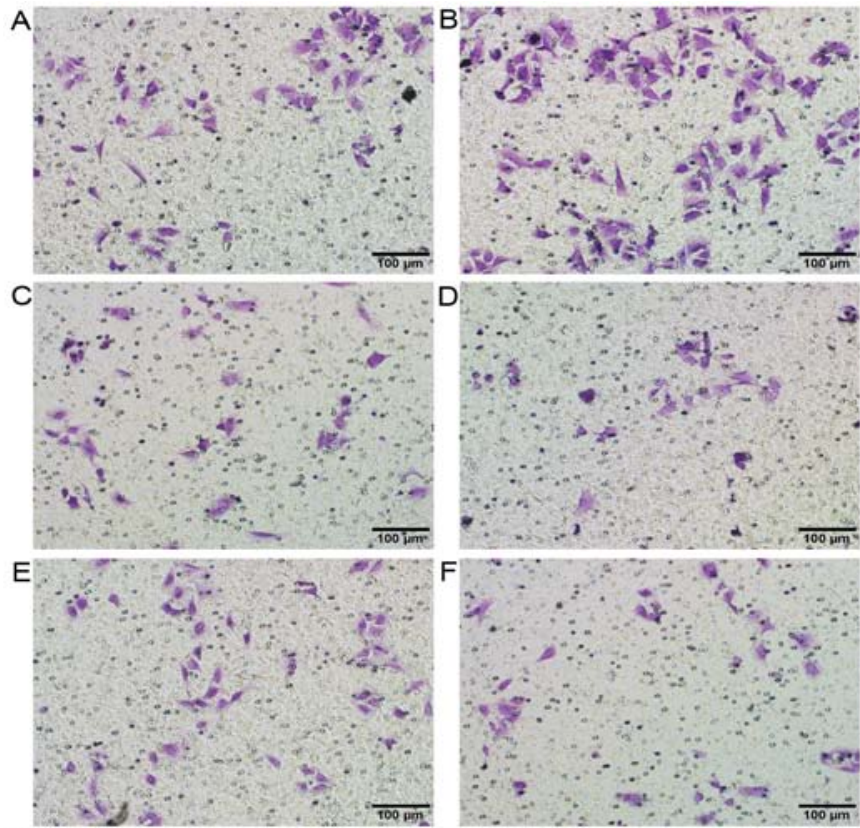

G

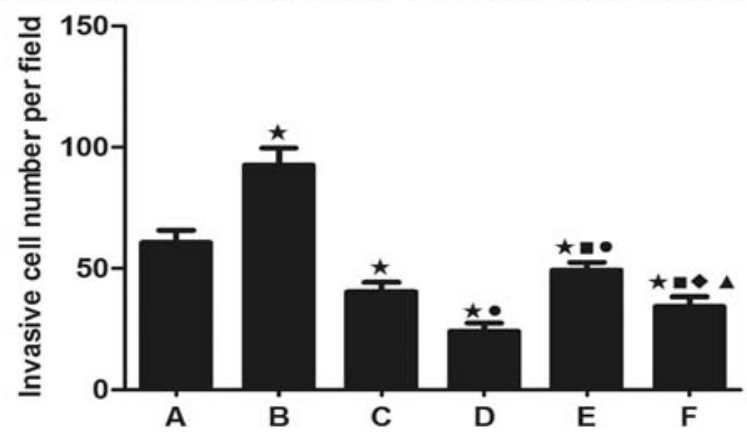

Figure 6. Detection of cell invasion. As in the assay of cell migration, the same phenomenon was observed in the detection of cell invasion. A difference from the control group $\left({ }^{\star} \mathrm{p}<0.05, \mathrm{t}=6.372,5.392,10.126,3.242\right.$ and 6.983); a difference from $\mathrm{X}$-ray irradiation group $(-\mathrm{p}<0.05, \mathrm{t}=9.717$ and 12.468); a difference from $\mathrm{L}_{50}\left({ }^{\bullet} \mathrm{p}<0.05, \mathrm{t}=5.223\right.$ and 3.019); a difference from $\mathrm{L}_{100}\left({ }^{\star} \mathrm{p}<0.05, \mathrm{t}=3.305\right)$; a difference from $\mathrm{X}+\mathrm{L}_{50}\left({ }^{\star} \mathrm{p}<0.05, \mathrm{t}=5.031\right)$.

to stimulate the tumor cell growth and promote invasiveness of different types of tumor cells in vitro by the upregulation of secreted proteases, such as MMPs and plasminogen activators (11-14). Other researchers have made similar findings in vivo. For instance, Camphausen et al (15) have reported that radiation therapy to a primary tumor accelerates metastatic growth in the Lewis lung cancer mouse model. So it is particularly important to find the effective combination therapy in order to get the best therapeutic efficacy in tumor treatment. LMWH has been reported effective for the treatment of metastasis to some extent, the mechanisms are proposed as anti-coagulation, inhibition of heparanase, selectins, adhesion, angiogenesis mediated by the tumor cells, and the effects on cell cycle and apoptosis $(6,16,17)$. Furthermore, clinical studies have suggested that LMWHs improve life expectancy of lung cancer patients (18-20). So, based on the above, we undertook this experiment to find out the therapeutic effect of nadroparin combined with radiation, and if so, whether there was a dose and time-response relationship for nadroparin also could be analyzed.

Results of our study showed that nadroparin and X-ray irradiation have synergistic antitumor effect in vitro. Nadroparin or

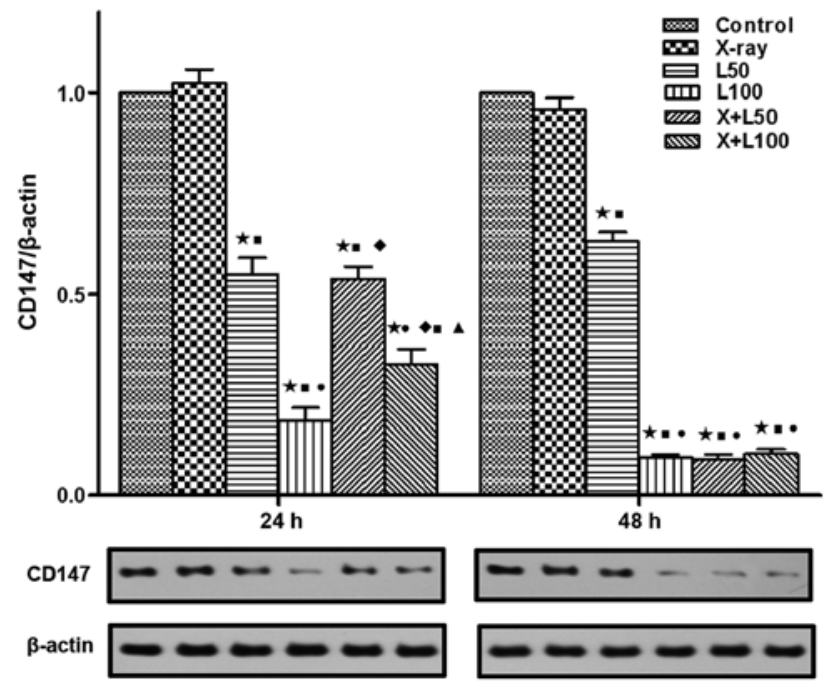

Figure 7. Expression of CD147. Western blotting demonstrated that CD147 protein expression was significantly different among each group at 24 and $48 \mathrm{~h}$ after treatment in the lower part of the picture while the upper part shows the relative expression in each treatment group compared to the control group. A difference from the control group $\left({ }^{\star} \mathrm{p}<0.05, \mathrm{t}=11.303\right.$, $24.867,15.121$ and 17.772 at $24 \mathrm{~h}, \mathrm{t}=15.858,114.959,80.418$ and 81.934 at $48 \mathrm{~h})$; a difference from $\mathrm{X}$-ray irradiation group $(\mathrm{m}<0.05, \mathrm{t}=8.918,17.447$, 10.419 and 13.493 at $24 \mathrm{~h}, \mathrm{t}=98.968,39.360,28.454$ and 28.151 at $48 \mathrm{~h}$ ); a difference from $\mathrm{L}_{50}(\bullet \mathrm{p}<0.05, \mathrm{t}=7.088$ and 4.083 at $24 \mathrm{~h}, \mathrm{t}=21.811,20.886$ and 20.507 at $48 \mathrm{~h}$ ); a difference from $\mathrm{L}_{100}\left({ }^{\star} \mathrm{p}<0.05, \mathrm{t}=7.902\right.$ and 2.811 at $\left.24 \mathrm{~h}\right)$; a difference from $\mathrm{X}+\mathrm{L}_{50}\left({ }^{\wedge} \mathrm{p}<0.05, \mathrm{t}=4.374\right.$ at $\left.24 \mathrm{~h}\right)$

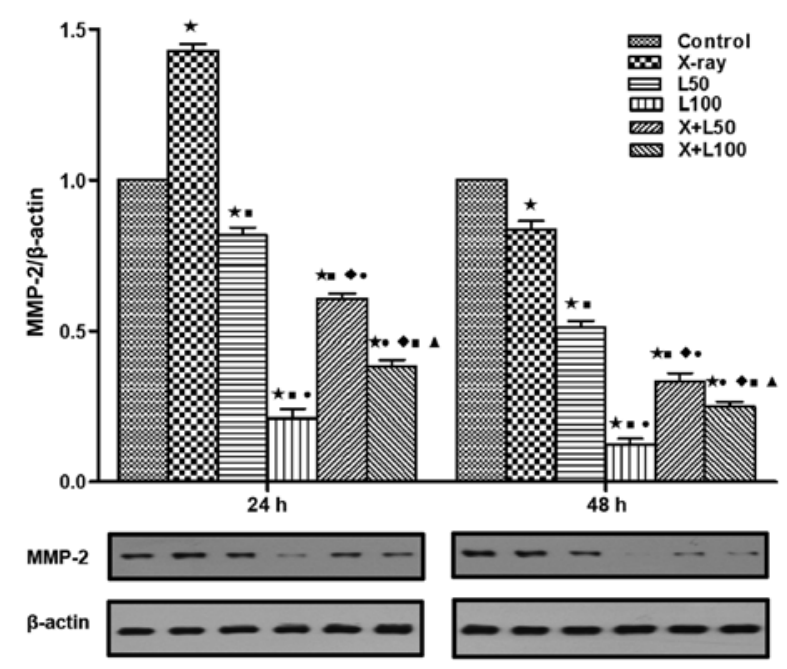

Figure 8. Expression of matrix metalloproteinase-2 (MMP-2). MMP-2 protein expression was significantly different among each group at 24 and $48 \mathrm{~h}$ after treatment by western blotting assay in the lower part of the picture. The upper part shows the relative expression in each treatment group compared to the control group. A difference from the control group $\left({ }^{\star} \mathrm{p}<0.05, \mathrm{t}=17.347\right.$, $7.186,26.075,21.443$ and 30.536 at $24 \mathrm{~h}, \mathrm{t}=5.932,20.911,47.308,25.276$ and 45.072 at $48 \mathrm{~h}$ ); a difference from $\mathrm{X}$-ray irradiation group $(-\mathrm{p}<0.05, \mathrm{t}=17.277$, $31.163,26.693$ and 32.715 at $24 \mathrm{~h}, \mathrm{t}=9.128,21.711,13.307$ and 18.514 at $48 \mathrm{~h}$ ); a difference from $\mathrm{L}_{50}\left({ }^{\bullet} \mathrm{p}<0.05, \mathrm{t}=15.407,6.763\right.$ and 13.405 at $24 \mathrm{~h}, \mathrm{t}=12.979$, 5.006 and 9.173 at $48 \mathrm{~h})$; a difference from $\mathrm{L}_{100}\left({ }^{\bullet} \mathrm{p}<0.05, \mathrm{t}=11.207\right.$ and 4.796 at $24 \mathrm{~h}, \mathrm{t}=6.553$ and 4.956 at $48 \mathrm{~h})$; a difference from $\mathrm{X}+\mathrm{L}_{50}\left({ }^{\star} \mathrm{p}<0.05, \mathrm{t}=8.160\right.$ at $24 \mathrm{~h}, \mathrm{t}=2.801$ at $48 \mathrm{~h}$ ).

X-ray irradiation alone could slightly inhibit the cell viability and enhance the cell apoptosis of A549 cells. The therapeutic effect of X-ray irradiation alone was more significant than that of nadroparin alone. Furthermore, the antitumor effect was 


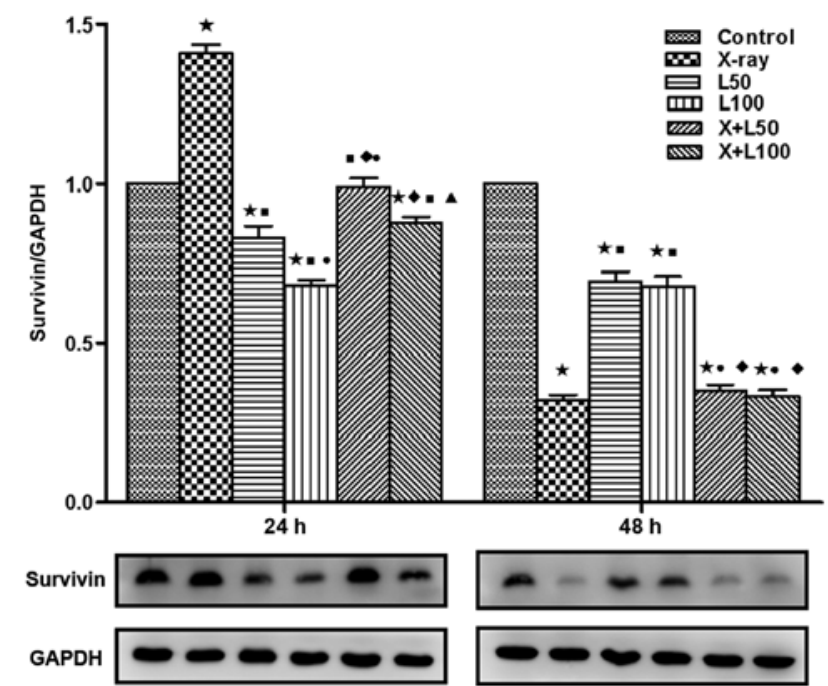

Figure 9. Expression of survivin. Similar to CD147 and matrix metalloproteinase-2 (MMP-2), survivin protein expression was also significantly different among each group at 24 and $48 \mathrm{~h}$ after treatment by western blotting. A difference from the control group $\left({ }^{\star} \mathrm{p}<0.05, \mathrm{t}=14.589,4.740,17.331\right.$ and 6.550 at $24 \mathrm{~h}, \mathrm{t}=39.077,10.495,10.076,35.048$ and 31.658 at $48 \mathrm{~h}$ ); a difference from $\mathrm{X}$-ray irradiation group $(\mathrm{p}<0.05, \mathrm{t}=12.797,21.690,10.421$ and 15.791 at $24 \mathrm{~h}, \mathrm{t}=11.130$ and 9.924 at $48 \mathrm{~h})$; a difference from $\mathrm{L}_{50}\left({ }^{\bullet} \mathrm{p}<0.05\right.$, $\mathrm{t}=3.789$ and 3.448 at $24 \mathrm{~h}, \mathrm{t}=10.006$ and 10.131 at $48 \mathrm{~h}$ ); a difference from $\mathrm{L}_{100}$ $(* \mathrm{p}<0.05, \mathrm{t}=8.997$ and 7.581 at $24 \mathrm{~h}, \mathrm{t}=8.903$ and 9.084 at $48 \mathrm{~h})$; a difference

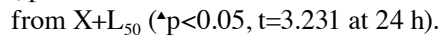

greatly improved in a dose- and time-dependent manner when these two treatments were combined.

TGF- $\beta$, a kind of multifunctional polypeptide, is closely related to the development of tumors. Three subunits defined as TGF- $\beta 1$, TGF- $\beta 2$ and TGF- $\beta 3$ have been cloned in mammals and the study of TGF- $\beta 1$ is the most profound and active. Many studies have shown that TGF- $\beta$ can enhance growth in a progressive tumor and the possible mechanisms for these growth enhancing effects were quite complex, including the enhanced angiogenesis $(21,22)$, increased peritumoral stroma formation and induced immunosuppression. In our study, with the prolonging of time, TGF- $\beta 1$ levels in the cell supernatants were increased in the control group while X-ray irradiation or low dose of nadroparin alone could slightly inhibit the increase of TGF- $\beta 1$ level. Moreover, TGF- $\beta 1$ levels were decreased when A549 cells were treated with high dose of nadroparin and the extent of this decrease was enhanced when combined with X-ray irradiation. This result suggested that the antitumor effect of nadroparin combined with X-ray irradiation may partially relate to the inhibition of TGF- $\beta 1$ secreted by A549 cells.

CD147, a member of the immunoglobulin superfamily, is overexpressed in a number of epithelial cell-derived carcinomas and is associated with tumor development and metastasis by activating the fibroblasts producing MMPs $(23,24)$. Wu et al $(25)$ found that CD147 induced resistance to ionizing radiation in hepatocellular carcinoma cells in vitro and in vivo. In our study, we found that nadroparin alone could inhibit the expression of CD147 and MMP-2 in a dose- and time-dependent manner. The expression levels of CD147 and MMP-2 were significantly lower in the combined treatment groups than the control group or X-ray irradiation group at the time of 24 and $48 \mathrm{~h}$ after treatment. Survivin, the smallest member of the inhibitor of apoptosis protein (IAP) family, encoded by a single gene located on the human $17 q 25$ chromosome with a molecular mass of $16.5 \mathrm{kDa}$, was first isolated by Ambrosini et al (26) at Yale University. The biological functions of survivin are also quite complex, including inhibiting tumor cell apoptosis $(27,28)$, promoting cell proliferation, participating in the regulation of cell cycle (29-31) and promoting blood vessel formation (32), which plays an important role in the development of cancer. Recently, increasing number of reports have shown that survivin is an independent prognostic factor for tumor therapy $(33,34)$. It has also showed that survivin overexpression has been correlated with elevated resistance to radiotherapy and chemotherapy in recent studies $(35,36)$. Investigations have reported that ionizing radiation at doses of 1 to $8 \mathrm{~Gy}$ is known to significantly elevate survivin levels in malignant cells (37-39). Therefore, blocking tumor cell survivin function or inhibiting its expression may inhibit cell apoptosis and proliferation and enhance its sensitivity to radiotherapy and chemotherapy. In our study, we found that nadroparin alone could inhibit the expression of survivin, which was dose-dependent, but not time-dependent. The expression of survivin was significantly upregulated by X-ray irradiation at the time of $24 \mathrm{~h}$ after treatment and this effect was inhibited by nadroparin in a dose-dependent manner. Based on the results above, we can conclude that the expression of CD147, MMP-2 and survivin was effectively and enduringly inhibited by nadroparin combined with X-ray irradiation in the whole process of the treatment. This result suggested that the antitumor effect of nadroparin combined with X-ray irradiation may partially relate to the inhibited expressions of CD147, MMP-2 and survivin in A549 cells.

Taken together, addition of nadroparin to combination radiotherapy resulted in a powerful synergistic antitumor effect in lung adenocarcinoma A549 cells. The mechanism may be associated with the induction of cell apoptosis, reduction of TGF- $\beta 1$ level, inhibition of cell invasion and migration and downregulated expression of CD147, MMP-2 and survivin. Importantly, these results revealed that nadroparin could inhibit the promotion of cell migration and invasion induced by radiotherapy in a dose-dependent manner. In brief, nadroparin combined with radiotherapy exerted a synergistic antitumor function, which may provide a novel strategy for cancer treatment. However, further investigations are required due to the complexity of structure and function of different LMWHs.

\section{Acknowledgements}

This study was supported by the Personnel Training Plan of Jinshan Hospital (2015-7).

\section{References}

1. Padera TP, Kadambi A, di Tomaso E, Carreira CM, Brown EB, Boucher Y, Choi NC, Mathisen D, Wain J, Mark EJ, et al: Lymphatic metastasis in the absence of functional intratumor lymphatics. Science 296: 1883-1886, 2002.

2. Mitrovska S and Jovanova S: Low-molecular weight heparin enoxaparin in the treatment of acute coronary syndromes without ST segment elevation. Bratisl Lek Listy 110: 45-48, 2009.

3. Mousa SA and Petersen LJ: Anti-cancer properties of low-molecular-weight heparin: Preclinical evidence. Thromb Haemost 102: 258-267, 2009. 
4. Icli F, Akbulut H, Utkan G, Yalcin B, Dincol D, Isikdogan A, Demirkazik A, Onur H, Cay F and Büyükcelik A: Low molecular weight heparin (LMWH) increases the efficacy of cisplatinum plus gemcitabine combination in advanced pancreatic cancer. $\mathrm{J}$ Surg Oncol 95: 507-512, 2007.

5. Yu CJ, Ye SJ, Feng ZH, Ou WJ, Zhou XK, Li LD, Mao YQ, Zhu W and Wei YQ: Effect of Fraxiparine, a type of low molecular weight heparin, on the invasion and metastasis of lung adenocarcinoma A549 cells. Oncol Lett 1: 755-760, 2010.

6. Carmazzi Y, Iorio M, Armani C, Cianchetti S, Raggi F, Neri T, Cordazzo C, Petrini S, Vanacore R, Bogazzi F, et al: The mechanisms of nadroparin-mediated inhibition of proliferation of two human lung cancer cell lines. Cell Prolif 45: 545-556, 2012.

7. Niu Q, Wang W, Li Y, Ruden DM, Wang F, Li Y, Wang F, Song J and Zheng K: Low molecular weight heparin ablates lung cancer cisplatin-resistance by inducing proteasome-mediated ABCG2 protein degradation. PLoS One 7: e41035, 2012.

8. Seidensticker M, Seidensticker R, Damm R, Mohnike K, Pech M, Sangro B, Hass P, Wust P, Kropf S, Gademann G, et al Prospective randomized trial of enoxaparin, pentoxifylline and ursodeoxycholic acid for prevention of radiation-induced liver toxicity. PLoS One 9: e112731, 2014

9. Bae SM, Kim JH, Chung SW, Byun Y, Kim SY, Lee BH, Kim IS and Park RW: An apoptosis-homing peptide-conjugated low molecular weight heparin-taurocholate conjugate with antitumor properties. Biomaterials 34: 2077-2086, 2013.

10. Erduran E, Tekelioğlu Y, Gedik Y and Yildiran A: Apoptotic effects of heparin on lymphoblasts, neutrophils, and mononuclear cells: Results of a preliminary in vitro study. Am J Hematol 61 90-93, 1999.

11. Jadhav U and Mohanam S: Response of neuroblastoma cells to ionizing radiation: Modulation of in vitro invasiveness and angiogenesis of human microvascular endothelial cells. Int J Oncol 29: 1525-1531, 2006.

12. Kaliski A, Maggiorella L, Cengel KA, Mathe D, Rouffiac V, Opolon P, Lassau N, Bourhis J and Deutsch E: Angiogenesis and tumor growth inhibition by a matrix metalloproteinase inhibitor targeting radiation-induced invasion. Mol Cancer Ther 4 : $1717-1728,2005$

13. Park CM, Park MJ, Kwak HJ, Lee HC, Kim MS, Lee SH, Park IC, Rhee $\mathrm{CH}$ and Hong SI: Ionizing radiation enhances matrix metalloproteinase-2 secretion and invasion of glioma cells through Src/epidermal growth factor receptor-mediated p38/Akt and phosphatidylinositol 3-kinase/Akt signaling pathways. Cancer Res 66: 8511-8519, 2006.

14. Zhai GG, Malhotra R, Delaney M, Latham D, Nestler U,Zhang M, Mukherjee N, Song Q, Robe P and Chakravarti A: Radiation enhances the invasive potential of primary glioblastoma cells via activation of the Rho signaling pathway. J Neurooncol 76 : 227-237, 2006

15. Camphausen K, Moses MA, Beecken WD, Khan MK, Folkman J and O'Reilly MS: Radiation therapy to a primary tumor accelerates metastatic growth in mice. Cancer Res 61: 2207-2211, 2001.

16. Norrby K: Low-molecular-weight heparins and angiogenesis. APMIS 114: 79-102, 2006

17. Debergh I, Van Damme N, Pattyn P, Peeters M and Ceelen WP The low-molecular-weight heparin, nadroparin, inhibits tumour angiogenesis in a rodent dorsal skinfold chamber model. Br J Cancer 102: 837-843, 2010.

18. Kakkar AK, Levine MN, Kadziola Z, Lemoine NR, Low V, Patel HK, Rustin G, Thomas M, Quigley M and Williamson RC: Low molecular weight heparin, therapy with dalteparin, and survival in advanced cancer: The fragmin advanced malignancy outcome study (FAMOUS). J Clin Oncol 22: 1944-1948, 2004.

19. Altinbas M, Coskun HS, Er O, Ozkan M, Eser B, Unal A, Cetin M and Soyuer S: A randomized clinical trial of combination chemotherapy with and without low-molecular-weight heparin in small cell lung cancer. J Thromb Haemost 2: 1266-1271, 2004.

20. Klerk CP, Smorenburg SM, Otten HM, Lensing AW, Prins MH, Piovella F, Prandoni P, Bos MM, Richel DJ, van Tienhoven G, et al: The effect of low molecular weight heparin on survival in patients with advanced malignancy. J Clin Oncol 23: 2130-2135, 2005.

21. Tuxhorn JA, McAlhany SJ, Yang F, Dang TD and Rowley DR: Inhibition of transforming growth factor-beta activity decreases angiogenesis in a human prostate cancer-reactive stroma xenograft model. Cancer Res 62: 6021-6025, 2002.
22. Li C, Guo B, Bernabeu C and Kumar S: Angiogenesis in breast cancer: The role of transforming growth factor beta and CD105. Microsc Res Tech 52: 437-449, 2001.

23. Kanekura $\mathrm{T}$ and Chen X: CD147/basigin promotes progression of malignant melanoma and other cancers. J Dermatol Sci 57: 149-154, 2010.

24. Weidle UH, Scheuer W, Eggle D, Klostermann S and Stockinger H: Cancer-related issues of CD147. Cancer Genomics Proteomics 7: 157-169, 2010.

25. Wu J, Li Y, Dang YZ, Gao HX, Jiang JL and Chen ZN: HAb18G/CD147 promotes radioresistance in hepatocellular carcinoma cells: A potential role for integrin $\beta 1$ signaling. Mol Cancer Ther 14: 553-563, 2015.

26. Ambrosini G, Adida C and Altieri DC: A novel anti-apoptosis gene, survivin, expressed in cancer and lymphoma. Nat Med 3: 917-921, 1997.

27. Tamm I, Wang Y, Sausville E, Scudiero DA, Vigna N, Oltersdorf T and Reed JC: IAP-family protein survivin inhibits caspase activity and apoptosis induced by Fas (CD95), Bax, caspases, and anticancer drugs. Cancer Res 58: 5315-5320, 1998

28. Suzuki A, Ito T, Kawano H, Hayashida M, Hayasaki Y, Tsutomi Y, Akahane K, Nakano T, Miura M and Shiraki K: Survivin initiates procaspase 3/p21 complex formation as a result of interaction with Cdk4 to resist Fas-mediated cell death. Oncogene 19: 1346-1353, 2000.

29. Li F, Ambrosini G, Chu EY, Plescia J, Tognin S, Marchisio PC and Altieri DC: Control of apoptosis and mitotic spindle checkpoint by survivin. Nature 396: 580-584, 1998.

30. Skoufias DA, Mollinari C, Lacroix FB and Margolis RL: Human survivin is a kinetochore-associated passenger protein. J Cell Biol 151: 1575-1582, 2000.

31. Suzuki A, Hayashida M, Ito T, Kawano H, Nakano T, Miura M, Akahane K and Shiraki K: Survivin initiates cell cycle entry by the competitive interaction with Cdk4/p16(INK4a) and Cdk2/cyclin E complex activation. Oncogene 19: 3225-3234, 2000

32. Nassar A, Lawson D, Cotsonis G and Cohen C: Survivin and caspase-3 expression in breast cancer: Correlation with prognostic parameters, proliferation, angiogenesis, and outcome. Appl Immunohistochem Mol Morphol 16: 113-120, 2008.

33. Monzó M, Rosell R, Felip E, Astudillo J, Sánchez JJ, Maestre J, Martín C, Font A, Barnadas A and Abad A: A novel anti-apoptosis gene: Re-expression of survivin messenger RNA as a prognosis marker in non-small-cell lung cancers. J Clin Oncol 17: 2100-2104, 1999.

34. Kren L, Brazdil J, Hermanova M, Goncharuk VN, Kallakury BV, Kaur P and Ross JS: Prognostic significance of anti-apoptosis proteins survivin and bcl-2 in non-small cell lung carcinomas: A clinicopathologic study of 102 cases. Appl Immunohistochem Mol Morphol 12: 44-49, 2004.

35. Yoshida H, Sumi T, Hyun Y, Nakagawa E, Hattori K, Yasui T, Morimura M, Honda K, Nakatani T and Ishiko O: Expression of survivin and matrix metalloproteinases in adenocarcinoma and squamous cell carcinoma of the uterine cervix. Oncol Rep 10: 45-49, 2003.

36. Ikeguchi M, Liu J and Kaibara N: Expression of survivin mRNA and protein in gastric cancer cell line (MKN-45) during cisplatin treatment. Apoptosis 7: 23-29, 2002.

37. Jin XD, Gong L, Guo CL, Hao JF, Wei W, Dai ZY and Li Q: Survivin expressions in human hepatoma HepG2 cells exposed to ionizing radiation of different LET. Radiat Environ Biophys 47: 399-404, 2008.

38. Rödel F, Reichert S, Sprenger T, Gaipl US, Mirsch J, Liersch T, Fulda $S$ and Rödel C: The role of survivin for radiation oncology: Moving beyond apoptosis inhibition. Curr Med Chem 18: 191-199, 2011.

39. Rödel C, Haas J, Groth A, Grabenbauer GG, Sauer R and Rödel F: Spontaneous and radiation-induced apoptosis in colorectal carcinoma cells with different intrinsic radiosensitivities: Survivin as a radioresistance factor. Int J Radiat Oncol Biol Phys 55: 1341-1347, 2003. 